\title{
Meat quality of Morada Nova lambs subjected to different feeding regimes
}

\section{Qualidade da carne de ovinos Morada Nova submetidos a diferentes manejos alimentares}

\author{
Antônio Clébio Ferreira da Silva ${ }^{1 *}$; Hélio Henrique Araújo Costa ${ }^{2}$; \\ Maria Claudete Rodrigues Peres ${ }^{1}$; Adailton Camêlo Costa ${ }^{1}$; \\ Diego Rodrigues de Sousa ${ }^{1}$; Ana Sancha Malveira Batista ${ }^{3}$; Aline Vieira Landim ${ }^{3}$
}

\begin{abstract}
This study aimed to evaluate the effect of pre- and post-calving feed restriction on quantitative characteristics and lipid profile of meat from Morada Nova sheep. Twenty-four male lambs from single births only, with an initial weight of $10.0 \pm 3.07 \mathrm{~kg}$ and at four months of age, were distributed in a randomized complete design, into three groups: pre-calving restriction (R-PRE; $n=8$ ) post-calving restriction (R-POS; $\mathrm{n}=8$ ), and ad libitum feeding ( $A D L I ; \mathrm{n}=8)$. To make up the experimental treatments, the feeding regime applied previously on the sheep in the last third of pregnancy was considered. Treatments $A D L I$ and R-POS were composed of lambs born from ewes fed ad libitum in the last third of pregnancy. Treatment R-PRE consisted of lambs born from ewes subjected to feed restriction in the last third of pregnancy at $60 \%$ of the recommended requirements for the group of ewes feeding ad libitum. For the lambs from treatments $A D L I$ and R-PRE, the diet was supplied allowing $20 \%$ of the total supplied as refusals. For the animals from R-POS, a 30\% restriction was imposed in relation to the animals feeding ad libitum. Animals were slaughtered with an average live weight of $25 \mathrm{~kg}$. Afterwards, carcasses were chilled at $4{ }^{\circ} \mathrm{C}$ for $24 \mathrm{~h}$. Meat quality measurements were taken on the right side of each carcass; $\mathrm{pH}$ was determined immediately after slaughter and then again after chilling. Samples of the longissimus dorsi muscle were collected and frozen at $-20^{\circ} \mathrm{C}$. Moisture, ash, protein, total lipids, water-holding capacity, and cooking loss were determined in the meat samples, which were then subjected to the shear-force test. The sensory analysis was determined by the hedonic-scale test, in which sensory parameters of tenderness, juiciness, flavor, aroma, and overall acceptability and fatty acid profile were evaluated. There was a feed-restriction effect on protein, lipids, and water-holding capacity $(\mathrm{P}<0.05)$. Meat sensory attributes were not influenced by the nutritional regimes $(\mathrm{P}>0.05)$. Saturated fatty acid contents were affected by the treatments $(\mathrm{P}<0.05)$; however, there was no effect of nutritional regimes on mono- or polyunsaturated fatty acids $(\mathrm{P}>0.05)$. Feed restriction does not compromise the physicochemical or sensory quality of Morada Nova lambs meat, but rather provides a meat product of good acceptance.
\end{abstract}

Key words: Feedlot. Feed restriction. Lipids. Sheep. Tenderness.

\footnotetext{
${ }^{1}$ Discentes, Dept ${ }^{\circ}$ de Zootecnia, Centro de Ciências Agrárias e Biológicas, CCAB, Universidade Estadual Vale do Acaraú, UVA, Sobral, CE, Brasil. E-mail: clebbio@gmail.com; claudete_zoot@yahoo.com.br; adailton07nr@hotmail.com; diego_drsk@ hotmail.com

2 Discente, Dept $^{\mathrm{o}}$ de Zootecnia, Escola de Veterinária, Universidade Federal de Minas Gerais, UFMG, Belo Horizonte, MG, Brasil. E-mail: helioa.costa@gmail.com

${ }^{3}$ Prof $^{\mathrm{a}}$, Dept ${ }^{\mathrm{o}}$ de Zootecnia, Centro de Ciências Agrárias e Biológicas, CCAB/UVA, Sobral, CE, Brasil. E-mail: anasancha@ yahoo.com.br; alinelandim@yahoo.com.br

* Author for correspondence
} 


\section{Resumo}

Objetivou-se avaliar o efeito da restrição alimentar pré e pós-natal sobre características qualitativas e do perfil lipídico da carne de ovinos da raça Morada Nova. Vinte e quatro cordeiros foram usados, machos, somente de parto simples, peso inicial 10,0 $\pm 3,07 \mathrm{~kg}$ e quatro meses de idade, distribuídos num delineamento inteiramente casualizado, em três grupos: restrição pré-natal (R-PRE; n=8) e pós-natal (R-POS; $\mathrm{n}=8$ ), e ad libitum ( $A D L I ; \mathrm{n}=8$ ). Para composição dos tratamentos experimentais foi considerado o manejo alimentar aplicado anteriormente nas ovelhas no terço final de gestação. Os tratamentos $A D L I$ e R-POS foram formados por cordeiros nascidos de ovelhas alimentadas ad libitum no terço final da gestação. O tratamento R-PRE foi constituído por cordeiros nascidos de ovelhas submetidas à restrição no terço final de gestação em $60 \%$ da recomendação das exigências do grupo de ovelhas ad libitum. Para os cordeiros dos tratamentos $A D L I$ e R-PRE a dieta foi fornecida permitindo-se sobras de $20 \%$ do total oferecido. Para os animais do tratamento R-POS foi imposto restrição de $30 \%$ em relação aos animais alimentados ad libitum. Os animais foram abatidos com peso vivo médio de $25 \mathrm{~kg}$. Após isso, as carcaças foram resfriadas a $4^{\circ} \mathrm{C}$ por 24 horas. As mensurações de qualidade da carne foram realizadas no lado direito de cada carcaça. $\mathrm{O}$ pH foi determinado imediatamente após o abate e novamente após o resfriamento. Foram coletadas amostras do músculo longissimus dorsi e congelados a $-20^{\circ} \mathrm{C}$. Na carne, foram determinados os teores de umidade, cinzas, proteína e lipídios totais, capacidade de retenção de água, perda de peso por cocção, em seguida, submetidas à determinação da força de cisalhamento. A análise sensorial foi determinada pelo teste da escala hedônica sendo avaliados parâmetros sensoriais de dureza, suculência, sabor, aroma, aceitação global, e o determinado o perfil de ácidos graxos. Houve efeito da restrição alimentar para proteína, lipídeos e capacidade retenção de água $(\mathrm{P}<0,05)$. Os atributos sensoriais da carne não foram influenciados pelos manejos nutricionais $(\mathrm{P}>0,05)$. Os teores de ácidos graxos saturados foram afetados pelos tratamentos $(\mathrm{P}<0,05)$, contudo, não houve efeito dos manejos nutricionais para ácidos graxos mono e poli-insaturados $(\mathrm{P}>0,05)$. A restrição alimentar não compromete a qualidade físico-química e sensorial da carne de cordeiros Morada Nova, e proporciona produto cárneo de qualidade e de boa aceitação.

Palavras-chave: Confinamento. Lipídios. Maciez. Ovinos. Restrição alimentar.

\section{Introduction}

Meat sheep farming is a growing activity all over Brazil. The demand for lamb meat in the country rose by $5 \%$ between the years 2000 and 2007, totaling a per capita consumption of 0.7 $\mathrm{kg}$ year $^{-1}$ (FAO, 2013). However, the demand for lamb meat can be considered low when compared with other meats such as beef, pork, and poultry (HERMUCHE et al., 2013a, 2013b). Some factors exert a great influence on lamb meat consumption, mainly those associated with eating habits and purchasing power (PAIM et al., 2011). Also according to these authors, the decisive factor for the expansion and consolidation of this market in Brazil is quality carcass production.

In meat production systems, the carcass qualitative characteristics are of paramount importance, since they are related to the end product
- the meat - and are influenced by genetic, sanitary, and nutritional factors. Feeding, for instance, is the factor of greatest impact in production systems, representing around $70-80 \%$ of total costs, determined by the technology level adopted on the farm.

To reduce feed costs in small-ruminant production, it is relevant to understand the aspects related to feed restriction, which may provide economic return to the producer, since this knowledge will allow for relationships to be established between the nutritional regime and tissue development at the different animal growth stages.

Research investigating the quality of meat from Morada Nova sheep subjected to different nutritional regimes is incipient. However, studies on other breeds have shown that imposing a feed 
restriction condition makes it possible to evaluate and understand this effect on the carcass tissue depositions (DANIEL et al., 2007). Therefore, the aim of the present study was to evaluate the effect of pre- and post-calving feed restriction on qualitative characteristics and on the lipid profile of Morada Nova lambs meat.

\section{Material and Methods}

The experiment was carried out on the Experimental Farm of the State University of Vale do Acaraú, in Sobral-CE, Brazil, complying with the criteria established by the ethics committee on animal use (no. 002.04.015.UVA.504.02). Twentyfour uncastrated male lambs from single births, with an average initial weight of $10.0 \pm 3.07 \mathrm{~kg}$, at four months of age, were allocated to individual stalls.

Calving type and order were considered in the choice of lambs and in the balancing and distribution of treatments. Only lambs from single births were utilized. Additionally, to make up the experimental treatments, the feeding regimes applied previously on the ewes during the last third of pregnancy were adopted.
The treatments ad libitum (ADLI; $\mathrm{n}=8)$ and post-calving restriction (R-POS; $\mathrm{n}=8$ ) included lambs born from ewes fed ad libitum in the last third of pregnancy. Treatment pre-calving restriction (R-PRE; $n=8$ ) comprised lambs born from ewes subjected to restriction in the last third of pregnancy, at $60 \%$ of the requirements recommended for the group of ewes feeding ad libitum. For the lambs from treatments $A D L I$ and R-PRE, the diets were supplied so that $20 \%$ of the total would be left as refusals. A $30 \%$ restriction was imposed on R-POS animals in relation to those fed ad libitum. Diets were supplied in two meals, at $08 \mathrm{~h} 30$ and $16 \mathrm{~h} 30$. Samples of feeds and refusals were weighed daily. Feed intake was adjusted weekly.

Animals underwent a period of 10 days of adaptation to experimental conditions. The diet was composed of antelope grass (Echinocloa pyramidalis) plus a concentrate based on maize, soybean meal, wheat bran, and limestone, formulated to meet the requirements of finishing lambs with an estimated weight gain of $150 \mathrm{~g} \mathrm{day}^{-1}$ (NRC, 2007) (Table 1). Water and mineral supplement were provided ad libitum.

Table 1. Chemical composition of ingredients and experimental diet.

\begin{tabular}{lccccc}
\hline \multirow{2}{*}{ Nutrient, \% } & \multicolumn{5}{c}{ Ingredient } \\
\cline { 2 - 5 } & Antelope grass $^{\dagger}$ & Maize & Soy. m. ${ }^{£}$ & ${\text { Wheat } b .{ }^{£}}$ & Diet \\
\hline Dry matter (DM) ${ }^{\beta}$ & 32.9 & 91.2 & 92.4 & 92.7 & 69.7 \\
Organic matter & & & & & \\
Crude protein & 85.2 & 89.8 & 86.4 & 86.9 & 85.5 \\
Neutral detergent fiber & 6.26 & 10.6 & 51.3 & 15.2 & 16.1 \\
Acid detergent fiber & 49.4 & 15.1 & 15.6 & 48.2 & 30.6 \\
Hemicellulose & 40.2 & 2.57 & 7.39 & 16.4 & 17.9 \\
Cellulose & 17.5 & 12.6 & 8.16 & 31.8 & 15.6 \\
Lignin & 64.9 & 2.48 & 14.9 & 12.5 & 27.1 \\
Total digestible nutrients & 5.93 & 0.39 & 1.25 & 4.23 & 2.87 \\
\hline
\end{tabular}

${ }^{\beta}$ Dry matter, on a fresh matter basis. ${ }^{\dagger}$ Echinocloa pyramidalis. ${ }^{\mathfrak{} S}$ Soybean meal and wheat bran. 
The animals were slaughtered with an average live weight of $25 \mathrm{~kg}$. Prior to slaughter, they were fasted for $16 \mathrm{~h}$. After fasting, lambs were stunned by brain concussion, followed by bleeding, according to commercial procedures and industrial and sanitary inspection regulatory rules for animal products (BRASIL, 1997). Afterwards, carcasses were chilled at $4{ }^{\circ} \mathrm{C}$ for $24 \mathrm{~h}$. Meat quality measurements were made on the right side of each carcass. The $\mathrm{pH}$ was determined immediately after slaughter, and again after chilling (24 h), using a digital potentiometer (DIGIMED, Model pH 300M, São Paulo, Brazil) equipped with a glass electrode and calibrated with a buffer solution with $\mathrm{pH} 7.0$ and $\mathrm{pH}$ 4.0. Samples of the longissimus dorsi muscle were collected and frozen at $-20{ }^{\circ} \mathrm{C}$.

Moisture (method 950.46), ash (method 920.153), and protein (method 984.13) were determined in the meat (AOAC, 1990). Total lipids were determined with chloroform and methanol 2:1 (FOLCH et al., 1957). Water-holding capacity was obtained by the technique of WeismerPedersen Grau and Hamm, modified by Sierra (1973). Cooking loss was determined according to Duckett et al. (1998). After cooking, samples were cut to dimensions of $2 \times 1 \times 1 \mathrm{~cm}$ and the shear force was determined on a Warner-Bratzler-Shear texturometer (WHEELER et al., 1996). Sensory analysis was performed using a hedonic scale (AMARINE et al., 1965; LARMOND, 1979), in which sensory parameters of tenderness, juiciness, flavor, aroma, and overall acceptance were evaluated.

The meat fatty acid profile was determined by chromatography, using samples of the longissimus dorsi muscle. Extraction was performed as described by Bligh and Dyer (1959), and methylation as in Molkentin and Prencht (2000).

Fatty acid concentrations were determined by the peak areas shown in the chromatogram for each acid in relation to the total area of the fatty acids. Data were expressed as a percentage of the area of each fatty acid. The nutritional quality of the lipid fraction was evaluated by indices obtained from the composition of the fatty acids. The atherogenicity index was calculated as proposed by Ulbricht and Southgate (1991) as an indicator for risk of cardiovascular disease. Calculations were made as follows:

Desirable fatty acids (AGD) $=$ monounsaturated fatty acids (MUFA) + polyunsaturated fatty acids (PUFA) + C18:0;

Atherogenicity index $(\mathrm{AI})=[(\mathrm{C} 12: 0+(4 \times$ $\mathrm{C} 14: 0)+\mathrm{C} 16: 0)] /$ total unsaturated; $\mathrm{C} 18: 0+\mathrm{C} 18: 1 /$ C16:0 ratio.

A randomized complete design with three treatments and eight replications was adopted. Proc GLM procedure of Statistical Analysis System SAS $^{\circledR} 9.0$ was utilized. Means were compared by Tukey's test. For the organoleptic attributes, the Kruskal-Wallis test was applied. Significance was declared at $\mathrm{P}<0.05$.

\section{Results and Discussion}

Feeding restriction did not influence the chemical composition or organoleptic attributes of the meat from Morada Nova lambs ( $\mathrm{P}>0.05$; Table 2), except for protein, lipids, and waterholding capacity. A higher protein content was observed for R-POS compared with R-PRE. The lipid fraction was higher for $\mathrm{R}-\mathrm{PRE}(\mathrm{P}<0.05)$, with a similar response observed for water-holding capacity (Table 2).

Animals in different nutritional plans, even of the same breed and with the same weight, differ in tissue composition (HAMMOND 1932, cited by LAWRIE, 2005). The lower lipid content in R-POS animals compared with R-PRE is possibly associated with the use of this fraction to meet the energy demands, since it is the first to be used, followed by protein. These tissues are utilized from late-maturing body regions, such as the longissimus dorsi muscle. 
At the same time, R-PRE animals displayed a greater lipid composition, which may be related to the animal responses under ad libitum feeding conditions, implying alterations in tissue distribution in an attempt to establish an energy reserve for a possible new feeding stress. In this study, we evaluated the effect of maternal dietary restriction during pregnancy on the characteristics of lamb meat, which resulted in decreased protein content, increasing the carcass fat:lean ratio (DANIEL et al., 2007). These authors reported that the change in fat content does not seem to be related to changes in protein content. By contrast, the more modest fetal growth in young ewes subjected to feed restriction is associated with a preservation of the growth of the fetal skeleton and depletion of the fetal fat storage.

Table 2. Effect of different nutritional regimes on Morada Nova lambs meat quality.

\begin{tabular}{lcccc}
\hline \multirow{2}{*}{ Variable } & \multicolumn{3}{c}{ Nutritional regime $^{\mathrm{f}}$} & \multirow{2}{*}{ SEM $^{¥}$} \\
\cline { 2 - 3 } Chemical attributes (\%) & ADLI & R-PRE & R-POS & \\
\hline Moisture & 74.3 & 73.8 & 74.3 & 0.141 \\
Ash & 0.950 & 0.890 & 0.860 & 0.017 \\
Protein & $17.6^{\mathrm{ab}}$ & $17.1^{\mathrm{b}}$ & $18.1^{\mathrm{a}}$ & 0.165 \\
Lipids & $7.16^{\mathrm{b}}$ & $8.24^{\mathrm{a}}$ & $6.68^{\mathrm{b}}$ & 0.207 \\
Physical attributes & & & & \\
Water-holding capacity (mL/100 g) & $54.7^{\mathrm{b}}$ & $66.0^{\mathrm{a}}$ & $55.3^{\mathrm{b}}$ & 2.08 \\
Cooking loss (\%) & 15.1 & 17.9 & 13.3 & 1.14 \\
Shear force (kgf/cm $\left.{ }^{2}\right)$ & 4.19 & 4.94 & 3.57 & 0.291 \\
Final pH & 5.62 & 5.58 & 5.70 & 0.026 \\
Organoleptic attributes ${ }^{\beta}(1-9)$ & & & & \\
Tenderness & 3.06 & 2.47 & 2.30 & 0.178 \\
Juiciness & 4.30 & 4.30 & 4.72 & 0.199 \\
Flavor & 4.93 & 5.07 & 5.10 & 0.178 \\
Aroma & 4.91 & 4.60 & 4.78 & 0.193 \\
Overall acceptance & 5.65 & 5.58 & 5.98 & 0.178 \\
\hline
\end{tabular}

${ }^{a}$ Means in the same row followed by different letters do not differ by Tukey's test $(\mathrm{P}<0.05) .{ }^{\beta}$ Kruskal-Wallis. ${ }^{\circledR}$ ADLI: ad libitum; R-PRE: pre-calving restriction; and R-POS: post-calving restriction. ${ }^{\ddagger} \mathrm{SEM}=$ standard error of the mean.

The water-holding capacity values are within the normal parameters (LAWRIE, 2005). However, the higher lipid content in R-PRE provided higher water retention. The average lipid contents of $7.70 \%$, despite the lack of differences in shear force $\left(4.23 \mathrm{kgf} \mathrm{cm}^{2-1}\right)$, provided meat with standard tenderness. Meat tenderness is an important attribute in terms of consumer satisfaction (ARGÜELLO et al., 2005). These authors reported that shear force values below 8 , between 8 and 11 , and above $11 \mathrm{kgf} \mathrm{cm}^{2-1}$ correspond to tender, medium-tenderness, and tough meat, respectively.

The $\mathrm{pH}$ value after chilling (5.63) was considered appropriate in the post mortem period, providing an adequate rigor mortis for muscle formation in the meat (LAWRIE, 2005). Reduced $\mathrm{pH}$ values are associated with care taken to avoid 
animal stress pre-slaughter; additionally, they are desirable, as they allow a greater activity of calpains and cathepsins, resulting in more tender meat (TEIXEIRA et al., 2005).

Thus, it is noteworthy that the critical functions of an animal depend on its levels of protein, fat, carbohydrates, minerals, and vitamins and water composition, which in turn influence the postcalving growth rate. Further, the skeletal muscle content, fat, connective tissues, and number of muscle fibers are the main factors that might affect the meat quality post mortem. Moreover, the intramuscular glycogen concentration and the glycolysis rate post-slaughter alter the meat lactic acid production and $\mathrm{pH}$, as well as its waterholding capacity (WU et al., 2006).

As regards the organoleptic aspects, the grades attributed to the meat tenderness and the lack of difference between nutritional regimes may be related to the amount of lipids present in the muscles. The Morada Nova lambs meat can be classified as of medium tenderness, given the average value of 2.61. This indicates that the meat from lambs under feeding restrictions meets the consumers' demands, since that is one of the main organoleptic characteristics appreciated in a meat.

The attributes of juiciness, flavor, aroma, color, and overall acceptance did not show significant differences between the feeding regimes, averaging $4.44,5.03,4.84,4.82$, and 5.73, respectively. For the attribute flavor, the similarity between treatments might have stemmed from the high lipid content of the meat. However, even being influenced by the dietary regime, this content was not sufficient to modify the flavor and aroma of the meat.
Eighteen fatty acids were found, divided into saturated (SFA; $\mathrm{n}=8$ ), monounsaturated (MUFA; $n=4$ ), and polyunsaturated (PUFA; $n=6$ ), in the meat of Morada Nova lambs under different nutritional regimes (Table 3).

The total SFA was higher for R-POS compared with R-PRE $(\mathrm{P}<0.05)$. There was no effect of feeding regimes on the fractionation of SFA $(\mathrm{P}>0.05)$, except for $\mathrm{C}: 18$, stearic acid, with higher concentrations in R-POS compared with $A D L I$ $(\mathrm{P}<0.05$; Table 3$)$. No effect of feeding regimes was observed on the mono- and polyunsaturated fatty acid contents, either $(\mathrm{P}>0.05)$. Analyzing the ratios between SFA, MUFA, and PUFA, and the total desirable fatty acids and the atherogenicity index, no effect of feed restriction was observed on these parameters, except for PUFA:SFA, which was higher for R-PRE compared with R-POS $(\mathrm{P}<0.05$; Table 3$)$.

Regarding the total fatty acids identified in the meat, higher concentrations of $\mathrm{C} 18: 1 \mathrm{n} 9 \mathrm{c}$ (oleic; 46.5\%), followed by $\mathrm{C} 16: 0$ (palmitic; 23.0\%), $\mathrm{C} 18: 0$ (stearic; 15.3\%), and $\mathrm{C} 18: 2 \mathrm{n} 6 \mathrm{c}$ (linoleic; $5.53 \%)$ were detected.

Oleic acid is usually the fatty acid found in largest quantity, and it features the ability to elevate blood high-density lipoprotein (HDL) levels (LOPES et al., 2012). On the other hand, among the classes of fatty acids present in the meat, only the sum of SFA was affected by the dietary regime. Besides, the hypercholesterolemic effect of the SFA is associated with the lower action of hepatic receptors for low-density lipoprotein (LDL), or 'bad cholesterol', elevating the circulating LDL in the blood plasma. 
Table 3. Effect of different nutritional regimes on the fatty acid profile of Morada Nova lambs meat.

\begin{tabular}{|c|c|c|c|c|}
\hline \multirow{2}{*}{ Variable } & \multicolumn{3}{|c|}{ Nutritional regime $^{\mathfrak{f}}$} & \multirow{2}{*}{ SEM } \\
\hline & $A D L I$ & R-PRE & R-POS & \\
\hline Saturated fatty acids (SFA) & $40.4^{\mathrm{ab}}$ & $39.8^{\mathrm{b}}$ & $42.8^{\mathrm{a}}$ & 0.59 \\
\hline C10:0 (capric) & n.d. & n.d. & 0.02 & - \\
\hline C12:0 (lauric) & n.d. & n.d. & 0.03 & - \\
\hline C14:0 (myristic) & 1.66 & 1.42 & 1.46 & 0.02 \\
\hline C15:0 (pentadecanoic) & 0.16 & 0.18 & 0.13 & 0.41 \\
\hline C16:0 (palmitic) & 23.4 & 22.3 & 23.3 & 0.08 \\
\hline $\mathrm{C} 17: 0$ (margaric) & 0.78 & 0.79 & 0.80 & 0.02 \\
\hline C18:0 (stearic) & $14.1^{\mathrm{b}}$ & $14.8^{\mathrm{ab}}$ & $16.9^{\mathrm{a}}$ & 0.03 \\
\hline C22:0 (behenic) & 0.19 & 0.21 & 0.15 & 0.03 \\
\hline Monounsaturated fatty acids (MUFA) & 49.2 & 47.4 & 47.1 & 0.92 \\
\hline C16:1 (palmitoleic) & 1.46 & 1.25 & 1.16 & 0.08 \\
\hline C17:1 (heptadecenoic) & 0.60 & 0.54 & 0.43 & 0.04 \\
\hline C18:1n9t (elaidic) & 0.76 & 0.98 & 0.80 & 0.09 \\
\hline C18:1n9c (oleic) & 47.8 & 45.9 & 45.8 & 0.94 \\
\hline Polyunsaturated fatty acids (PUFA) & 11.6 & 8.95 & 8.93 & 1.22 \\
\hline C18:2n6c (linoleic) & 4.96 & 6.43 & 5.19 & 0.64 \\
\hline C18:2c9t11 (rumenic) & 0.67 & 0.44 & 0.39 & 0.04 \\
\hline C18:2t10c12 (CLA) & 0.72 & 0.41 & 0.26 & 0.07 \\
\hline C18:3n6 (y-linolenic) & 0.03 & 0.82 & 0.02 & 0.01 \\
\hline C18:3n3 ( $\alpha$-linolenic) & 0.20 & 0.24 & 0.19 & 0.02 \\
\hline $\mathrm{C} 20: 4 \mathrm{n} 6$ (arachidonic) & 2.37 & 4.13 & 2.71 & 0.58 \\
\hline MUA:SFA & 1.22 & 1.19 & 1.10 & 0.02 \\
\hline PUFA:SFA & 0.22 & 0.31 & 0.21 & 0.03 \\
\hline UFA:SFA & $1.44^{\mathrm{ab}}$ & $1.50^{\mathrm{a}}$ & $1.31^{\mathrm{b}}$ & 0.04 \\
\hline Desirable fatty acids & 72.3 & 73.8 & 72.9 & 0.50 \\
\hline Atherogenicity index & 0.46 & 0.42 & 0.46 & 0.02 \\
\hline
\end{tabular}

${ }^{a}$ Means in the same row followed by different letters do not differ by Tukey’s test $(\mathrm{P}<0.05) .{ }^{*} \mathrm{SEM}=$ standard error of the mean; $\mathrm{n}$.d. $=$ not determined. ${ }^{\ddagger} \mathrm{ADLI}$ : ad libitum; R-PRE: pre-calving restriction; and R-POS: post-calving restriction.

French et al. (2003) reported that the most desirable fatty acid would be myristic acid (C14:0), which represented $1.51 \%$ of the total saturated fatty acids in the meat. Linoleic and conjugated linoleic acids (CLA), in turn, had mean values of 0.21 and $5.52 \%$, respectively. The latter is a polyunsaturated fatty acid, and an increase in the concentrations of these acids in animal products is desirable, because of their anticarcinogenic, anti-atherosclerotic, antithrombotic, hypercholesterolemic, and immunostimulatory properties, in addition to increasing muscle mass while reducing body fat and preventing diabetes (MOREIRA et al., 2003).

The average PUFA:SFA ratio was 0.25. A PUFA:SFA ratio lower than 0.45 indicates little healthy foods, mainly with regard to cardiovascular disease (DEPARTMENT OF HEALTH AND SOCIAL SECURITY, 1984). Low values for this ratio are commonly expected, since ruminants have higher proportions of saturated fatty acids due to an intense hydrogenation of diet components from the action of rumen microorganisms (FRENCH et 
al., 2000). However, it must be taken into account that the percentage of stearic acid can be converted to oleic acid, increasing the UFA:SFA ratio, providing beneficial effects to the human health.

The observed MUFA:SFA ratio was 1.17. This occurrence may be linked to the high oleic acid contents and a consequent increase in MUFA:SFA, suggesting that Morada Nova sheep meat has its lipid fraction favorable to human consumption. These results are close to those found for sheep meat by Rhee et al. (2003), who obtained 1.05 to 1.21 .

The desirable fatty acids content and the atherogenicity index (AI) were $73.0 \%$ and 0.447 , respectively. The AI has been utilized as an indicator of dietary risk for cardiovascular disease. There is no standard value that can be used to indicate risk for development of some diseases such as cancer, diabetes, among others are associated with the ingestion of meats. However, it is noteworthy that the meat represents only one of the ingredients of the human diet, and thus the meat triglycerides content should not be regarded alone, but rather the total contents contained in the consumed diet. Meat consumption should be recommended, as this product contains fatty acids beneficial to the human health, e.g. oleic acid and CLA. The latter is found only in animal products, notably in ruminants (LOPES et al., 2012).

\section{Conclusion}

Feed restriction does not compromise the physicochemical or sensory quality of meat from Morada Nova sheep, but rather provides a meat product of quality and good acceptance.

\section{Acknowledgments}

The authors thank Conselho Nacional de Desenvolvimento Cientifico e Tecnológico - CNPq for financially supporting the research project.

\section{References}

AMARINE, M. A.; PANGBORN, M. R.; ROESSLER, E. B. Principles of sensory evaluation of food. New York: Academic Press, 1965. 602 p.

ARGÜELlO, A.; CASTRO, N.; CAPOTE, J; SOLOMON, M. Effects of diets and live weight at slaughter on kids meat quality. Meat Science, Cowra, v. 70, n. 1, p. 173-179, 2005.

BLIGH, E. G.; DYER, W. J. A rapid method of total lipid extraction and purification. Canadian Journal of Biochemistry and Physiology, Ottawa, v. 37, n. 8, p. 911917, 1959.

BRASIL. Decreto n. 30.691, alterado pelos Decretos n. 1.255 de $25-06-62$, n. 1236 de 02-09-94, n. 1.812 de 08-02-96 e n. 2. 244 de 04-06-97. Aprova o regulamento da inspeção industrial e sanitária de produtos de origem animal (RIISPOA). Lex: Diário Oficial [da] União, Brasília, 5 jul. 1997, seção 1, p. 11555.

DANIEL, Z. C. T. R.; BRAMELD, J. M.; CRAIGON, J.; SCOLLAN, N. D.; BUTTERY, P. J. Effect of maternal dietary restriction during pregnancy on lamb carcass characteristics and muscle fiber composition. Journal of Animal Science, Champaign, v. 85, n. 6, p. 1565-1576, 2007.

DEPARTMENT OF HEALTH AND SOCIAL SECURITY. Diet and cardiovascular disease. Meat Science, Cowra, v. 42, n. 28, p. 443-456, 1984.

DUCKETT, S. K.; KLEIN, T. A.; DODSON, M. V.; SNOWDER, G. D. Tenderness of normal and callipyge lamb aged fresh or after freezing. Meat Science, Cowra, v. 49 , n. 1, p. 19-26, 1998.

FOLCH, J.; LESS, M.; STANLEY, S. A simple method for the isolation and purification of total lipids from animal tissues. Journal Biological Chemistry, Birmingham, v. 226, n. 1, p. 497-509, 1957.

FOOD AND AGRICULTURE ORGANIZATION - FAO. Estatísticas - FAOSTAT. 2013. Available at: <http:// faostat.fao.org >. Accessed at: 06 feb. 2016.

FRENCH, P.; O'RIORDAN, E. G.; MONAHAN, F. J.; CAFFREY P. J.; MOLONEY A. P. Fatty acid composition of intra-muscular triacylglycerols of steers fed autumn grass and concentrates. Livestock Production Science, Amsterdam, v. 81, n. 2, p. 307-317, 2003.

FRENCH, P.; STANTON, C.; LAWLESS, F.; O'RIORDAN, E. G.; MONAHAN, F. J.; CAFFREY, P. J.; MOLONEY, A. P. Fatty acid composition, including conjugated linoleic acid of intramuscular fat from steers offered grazed grass, grass silage or concentrate based 
diets. Journal of Animal Science, Champaign, v. 78, n. 5, p. 2849-2855, 2000.

HERMUCHE, P. M.; VIEIRA, D. L. M.; SANO, E. E. Modeling tree cover changes in a pasture dominated landscape by adopting silvopastoral practices in a dry forest region in Central Brazil. Agroforestry Systems, Dordrecht, v. 87, n. 4, p. 881-890, 2013 a.

HERMUCHE, P. M.; MARANHÃO, R. L. A.; GUIMARÃES, R. F.; CARVALHO JÚNIOR, O. A.; GOMES, R. A. T.; PAIVA, S. R.; MCMANUS, C. Dynamics of sheep production in Brazil. ISPRS International Journal of Geo-Information, Basel, v. 2, n. 3, p. 665-679, 2013b.

LARMOND, E. Laboratory methods for evaluation of foods. Ottawa: Food Research Institute/Canada Department of Agriculture, 1979. 432 p.

LAWRIE, R. A. Ciência da carne: constituição química e bioquímica do músculo. Porto Alegre: Artimed, 2005. $384 \mathrm{p}$.

LOPES, L. S.; LADEIRA, M. M.; MACHADO NETO, O. R.; RAMOS, E. M.; PAULINO, P. V. R.; CHIZZOTTI, M. L.; GUERREIRO, M. C. Composição química e de ácidos graxos do músculo longissimus dorsi e da gordura subcutânea de tourinhos Red Norte e Nelore. Revista Brasileira de Zootecnia, Viçosa, MG, v. 41, n. 4, p. 978985, 2012.

MOLKENTIN, J.; PRENCHT, J. M. D. Validation of gas-chromatography method for the determination of milk fat by butyric acid analysis. Journal of Science and Technology, Kumasi, v. 102, n. 3, p. 194-201, 2000.

MOREIRA, F. B.; SOUZA, N. E.; MATSUSHITA, M.; PRADO, I. N.; NASCIMENTO, W. G. Evaluation of carcass characteristics and meat chemical composition of Bos indicus and Bos indicus x Bos taurus crossbred steers finished in pasture systems. Brazilian Archives of Biology and Technology, Curitiba, v. 46, n. 4, p. 607-614, 2003.
NATIONAL RESEARCH COUNCIL - NRC. Nutrients requirements of small ruminants: sheep, goats, cervids and new world camelids. Washington, D. C.: National Academy Press, 2007. 384 p.

OFFICIAL METHODS OF ANALYSIS - AOAC. $15^{\text {th }}$ ed. rev. Gaithersburg: Association of Official Analytical Chemistis, 1990.

PAIM, T. P.; CARDOSO, M. T. M.; BORGES, B. O.; GOMES, E. F.; LOUVANDINI, L.; McMANUS, C. Estudo econômico da produção de cordeiros cruzados confinados abatidos em diferentes pesos. Ciência Animal Brasileira, Goiânia, v. 12, n. 1, p. 48-57, 2011.

RHEE, K. S.; LUPTON, C. J.; ZIPRIN, Y. A.; RHEE, K. C. Effects of sheep production systems on oxidative storage stability of lean lamb patties. Meat Science, Cowra, v. 65, n. 2, p. 701-706, 2003.

SIERRA, I. Producción de cordero joven y pesado en la raza Rasa Aragonesa. Instituto de Economía y Producciones Ganaderas del Ebro, Zaragoza, n. 18, p. 1-28, 1973.

TEIXEIRA, A.; BATISTA, S.; DELFA, R.; CADAVEZ, $\mathrm{V}$. Lamb meat quality of two breeds with protected origin designation. Influence of breed, sex and live weight. Meat Science, Cowra, v. 71, n. 3, p. 530-536, 2005.

ULBRICHT, T. L. V.; SOUTHGATE, D. A. T. Coronary heart disease: seven dietary factors. The Lancet, London, v. 338, n. 8773, p. 985-992, 1991.

WHEELER, T. L.; CUNDIFF, L. V.; KOCH, R. M. Characterization of biological types of cattle (Cycle IV): carcass traits and longissimus palatability. Journal of Animal Science, Champaign, v. 74, n. 5, p. 1023-1035, 1996.

WU, G.; BAZER, F. W.; WALLACE, J. M.; SPENCER, T. E. Intrauterine growth retardation: implications for the animal sciences. Journal of Animal Science, Champaign, v. 84, n. 9, p. 2316-2337, 2006. 
